Review

\title{
Animal Models for DOHaD Research: Focus on Hypertension of Developmental Origins
}

\author{
Chien-Ning Hsu ${ }^{1,2}$ (D) and You-Lin Tain ${ }^{3,4, *(D)}$ \\ 1 Department of Pharmacy, Kaohsiung Chang Gung Memorial Hospital, Kaohsiung 833, Taiwan; \\ cnhsu@cgmh.org.tw \\ 2 School of Pharmacy, Kaohsiung Medical University, Kaohsiung 807, Taiwan \\ 3 Department of Pediatrics, Kaohsiung Chang Gung Memorial Hospital and Chang Gung University College of \\ Medicine, Kaohsiung 833, Taiwan \\ 4 Institute for Translational Research in Biomedicine, Kaohsiung Chang Gung Memorial Hospital, \\ Chang Gung University College of Medicine, Kaohsiung 833, Taiwan \\ * Correspondence: tainyl@cgmh.org.tw; Tel.: +886-975-056-995; Fax: +886-7733-8009
}

Citation: Hsu, C.-N.; Tain, Y.-L. Animal Models for DOHaD Research Focus on Hypertension of Developmental Origins. Biomedicines 2021, 9, 623. https://doi.org/ $10.3390 /$ biomedicines 9060623

Academic Editor: Martina Perše

Received: 4 May 2021

Accepted: 28 May 2021

Published: 31 May 2021

Publisher's Note: MDPI stays neutral with regard to jurisdictional claims in published maps and institutional affiliations.

Copyright: (c) 2021 by the authors. Licensee MDPI, Basel, Switzerland. This article is an open access article distributed under the terms and conditions of the Creative Commons Attribution (CC BY) license (https:// creativecommons.org/licenses/by/ $4.0 /)$.

\begin{abstract}
Increasing evidence suggests that fetal programming through environmental exposure during a critical window of early life leads to long-term detrimental outcomes, by so-called developmental origins of health and disease $(\mathrm{DOHaD})$. Hypertension can originate in early life. Animal models are essential for providing convincing evidence of a causal relationship between diverse earlylife insults and the developmental programming of hypertension in later life. These insults include nutritional imbalances, maternal illnesses, exposure to environmental chemicals, and medication use. In addition to reviewing the various insults that contribute to hypertension of developmental origins, this review focuses on the benefits of animal models in addressing the underlying mechanisms by which early-life interventions can reprogram disease processes and prevent the development of hypertension. Our understanding of hypertension of developmental origins has been enhanced by each of these animal models, narrowing the knowledge gap between animal models and future clinical translation.
\end{abstract}

Keywords: animal model; developmental origins of health and disease (DOHaD); hypertension; oxidative stress; pregnancy; renin-angiotensin system; gut microbiota; reprogramming

\section{Introduction}

The association between fetal development and the increased risk of adult disease has attracted a great deal of attention to the concept of developmental programming or developmental origins of health and disease (DOHaD) [1,2]. The DOHaD hypothesis gained momentum after the emergence of observational studies from the 1944-1945 Dutch famine cohort, illustrating that maternal starvation is associated with an increased risk of metabolic and cardiovascular diseases in adult offspring [3]. These findings, combined with numerous subsequent epidemiologic investigations, indicate that the perinatal period, a critical window of organogenesis, is a vulnerable time in terms of the impact of adverse environmental insults [4]. Several hypotheses, such as thrifty phenotype [5], maternal capital [6], and predictive adaptive responses [7], have been developed to explain the epidemiological observations of an association between early life insults and diseases in adulthood. However, these hypotheses do not propose mechanistic pathways by which disease proceeds or suggest potential interventions for the prevention of adult diseases. Accordingly, animal models that have been developed and characterized have been instrumental in indicating the biological plausibility of the associations observed in epidemiological research, providing proof of causality. Emerging evidence indicates that animal models are valuable tools for understanding the pathogenesis of developmental programming and developing therapeutic interventions for DOHaD-related diseases [8-10]. A variety of small (e.g., rats, 
mice, and guinea pigs) and large (e.g., sheep and pigs) animals have been used to test aspects of the DOHaD hypothesis, and each offers different advantages.

Hypertension and related cardiovascular diseases are leading causes of mortality worldwide [11]. The WHO reported that 1 in 4 men and 1 in 5 women have hypertension [12]. Due to the multifactorial nature of hypertension, the use of various animal models, which induce hypertension by various mechanisms and produce the same end result, is advantageous $[13,14]$. In the past decades, novel drug classes and interventional strategies for the treatment of hypertension have been developed using hypertensive animal models [15]. However, the prevalence of hypertension remains high and continues to increase globally [16]. All this raises the question of how to prevent and not just treat hypertension based on the $\mathrm{DOHaD}$ concept.

A broad range of early-life insults can induce developmental programming, resulting in hypertension. These include maternal undernutrition or overnutrition, maternal disease states, lifestyle changes, substance abuse, environmental exposure to toxins/chemicals, and medication use during pregnancy [10,17-20]. Hypertension, diabetes, kidney disease, and inflammation are common maternal diseases that complicate pregnancy. On the other hand, programming processes geared toward disease could be reversed by shifting therapy from adulthood to the perinatal period, that is to say, by reprogramming [21]. Although the pathogenesis behind hypertension of developmental origins is poorly understood at present, our understanding of animal models used to study common mechanistic pathways has advanced greatly in recent years, which helps in developing efficient strategies to reprogram hypertension and prevent it from happening.

This review summarizes the contributions of animal models to $\mathrm{DOHaD}$ research with a focus on hypertension. It is proposed that integrating evidence from diverse animal models is essential in order to advance our understanding of hypertension of developmental origins and develop novel reprogramming strategies to alleviate the global burden of hypertension.

We retrieved related literature from all articles indexed in PubMed/MEDLINE. Search terms were as follows: "blood pressure", "developmental programming", "DOHaD", "animal model", "mother", "maternal", "pregnancy", "gestation", "offspring", "progeny", "prenatal", "perinatal", "reprogramming", and "hypertension". Additional studies were then selected and assessed based on appropriate references in eligible papers. The last search was conducted on 20 April 2021.

\section{Choice of Animal Models}

A broad range of animal models have been established to validate that the associations found in human observational studies can be replicated under experimental conditions. Animal models can be categorized in many different ways. First, models for DOHaD research can be categorized by types of environmental insult. For example, global caloric restriction and protein restriction in animals can mimic the starvation associated with famine in human cohorts [8,9]. Second, animal models can be classified according to molecular mechanisms. Since different environmental insults during pregnancy and lactation produce similar outcomes with respect to hypertension in adult offspring, there might be common mechanisms behind the developmental programming of hypertension. To date, hypertension of developmental origins has been attributed to mechanisms $[10,17-21]$ including reduced nephron number, oxidative stress, an aberrant renin-angiotensin system (RAS), gut microbiota dysbiosis, and sex differences, among others. Animal models have been developed to test such proposed mechanisms. Finally, various small- and large-animal models have been established for $\mathrm{DOHaD}$ research, each with its own natural advantages and disadvantages [8]. Although non-human primates have long been regarded as the gold standard because of their high genetic and biological similarity to humans, the most commonly used species in the DOHaD field are rodents [22]. Rat and mouse models provide a low-cost option with a short life cycle that is easy to handle. Mice also provide ample access that allows for genetic modification. Depending on the experimental approach, other 
species such as rabbits, sheep, and pigs have also been used to evaluate developmental programming related to offspring outcomes [22]. Rabbits are useful for studies as their lipid metabolism and placental structure are similar to those in humans [23]. Pigs are considered to be a suitable model for evaluating the early stages of fertilization and development. Sheep have a long gestation period, and their fetal size and developmental rate are close to those in humans [24]. Cows are large, monotocous animals with a long gestation period, as in humans [24]. Thus, many aspects of animal models have to be taken into consideration when choosing one species over another, such as genetic background, anatomy, physiology, length of gestation, litter size, life cycle, and application to the clinical context. A summary of the selection of animal models for the study of hypertension of developmental origins is depicted in Figure 1.

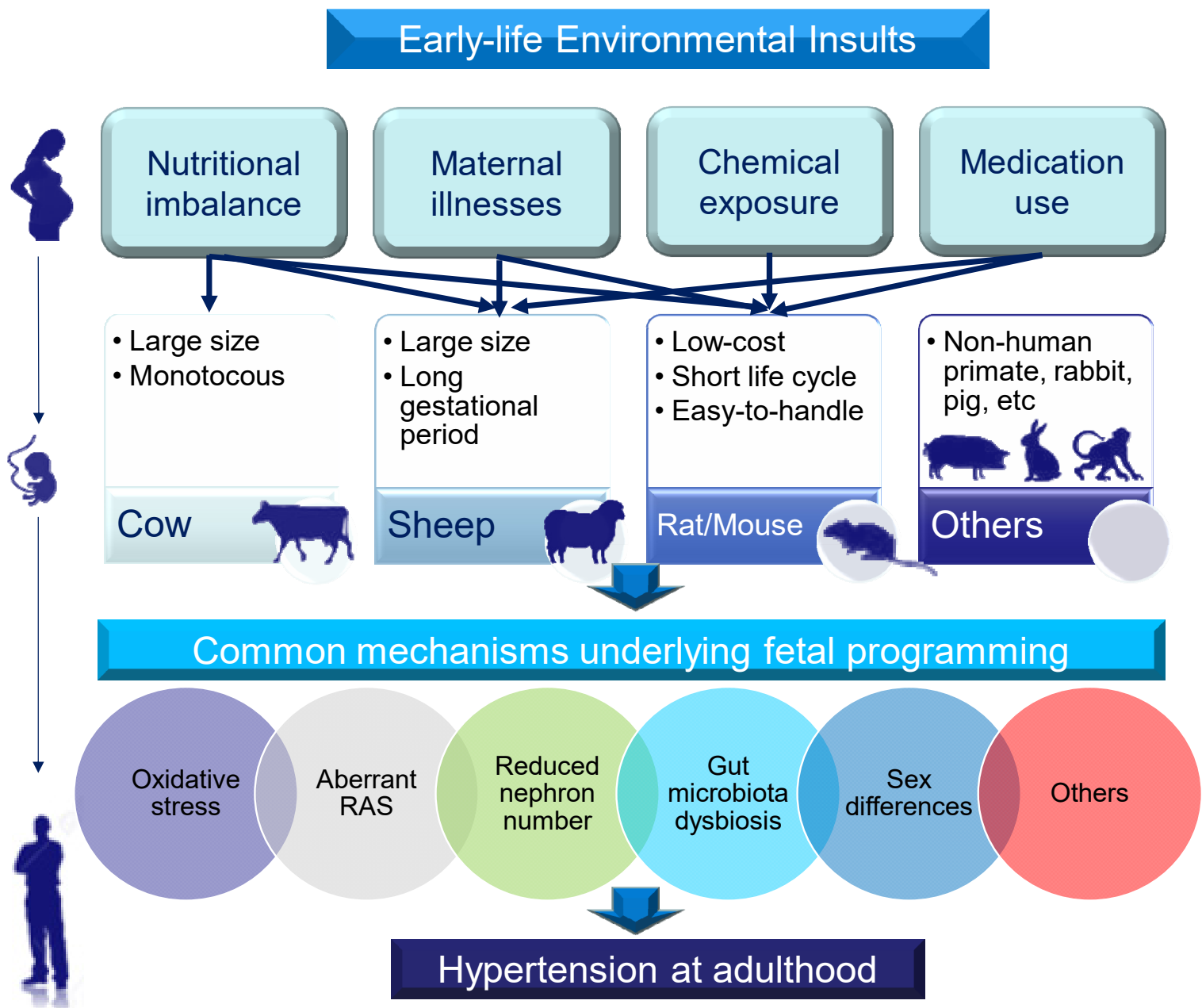

Figure 1. Schematic illustration of the selection of animal models for studying hypertension of developmental origins in adulthood according to early-life environmental insults, animal species, and common mechanisms. Lines with arrows (top section) indicate types of early-life insults produced in particular species of animals to induce hypertension in adult offspring. The study of other animals in DOHaD research (non-human primates, rabbits, pigs, etc.) is limited.

\section{Hypertension of Developmental Origins: Early-Life Insults}

Several suboptimal environmental conditions during fetal development are relevant to hypertension in adult offspring, including maternal nutritional imbalance, maternal illnesses and conditions, exposure to environmental chemicals, and medication use during pregnancy and lactation [10,17-20]. Each category is discussed in turn. 


\subsection{Maternal Nutritional Imbalance}

Within the context of $\mathrm{DOHaD}$ research, studies of nutritional programming using small animal models have been ongoing since the early 1990s [8]. Nutritional interventions during critical developmental phases can have long-lasting effects on blood pressure (BP) in adult offspring [17]. Excessive or insufficient consumption of a specific nutrient has been used to induce hypertension of developmental origins in animal models, as shown in Figure 2 [25].

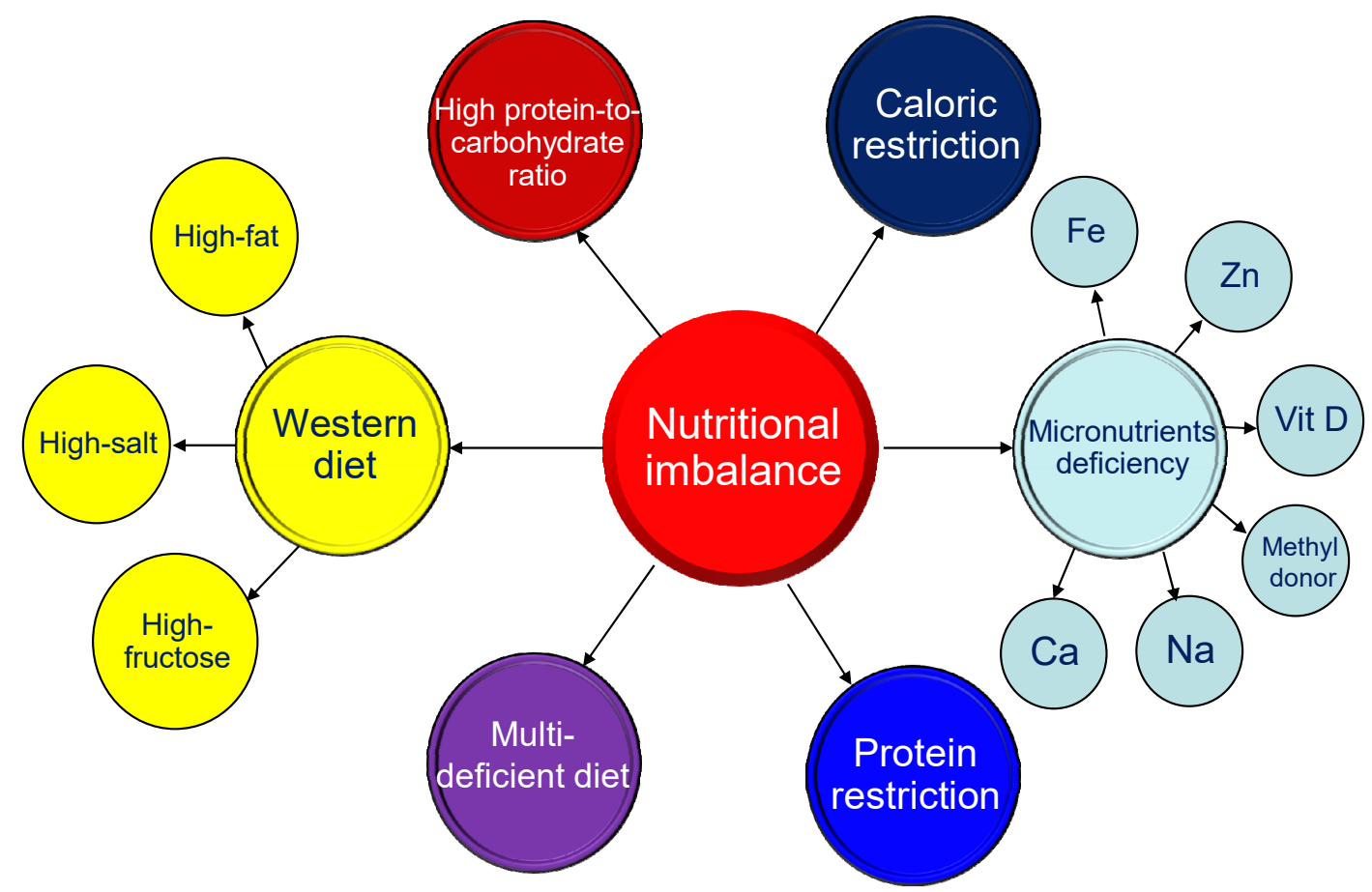

Figure 2. Overview of nutritional interventions used to modulate nutritional status during pregnancy and/or lactation to study hypertension of developmental origins in animal models. Fe = iron; $\mathrm{Zn}=$ zinc; Vit $\mathrm{D}=$ vitamin $\mathrm{D} ; \mathrm{Na}=$ sodium; $\mathrm{Ca}=$ calcium.

Caloric restriction refers to an overall reduction of energy and nutrient intake without incurring malnutrition. Caloric restriction in a range of $30-70 \%$ in pregnant rats has been reported to induce elevated BP in their adult offspring [26-28]. Hypertension programmed by maternal caloric restriction has also been observed in other species, including sheep $[29,30]$ and cows [31]. In general, more severe caloric restriction resulted in earlier development of hypertension in adult offspring [25]. The protein restriction model has also been widely used to explore the mechanisms of nutritional programming [32]. As in the caloric restriction model, when pregnant rats were exposed to a greater degree of protein restriction, their adult offspring were likely to have high BP earlier [33-35]. Moreover, deficiencies in micronutrients, including iron [36], zinc [37], vitamin D [38], methyl donor nutrients (folic acid; choline; methionine; and vitamins B2, B6, and B12) [39], sodium [40], and calcium [41] in pregnant rats were associated with hypertension in their offspring. In a Brazilian study, when dams were fed with a multi-deficient diet developed from a basic regional diet, this was also shown to induce hypertension in adult rat offspring [42,43]. On the other hand, the excessive intake of certain nutrients can result in programmed hypertension in male adult offspring [25]. The Western diet is a modern dietary pattern characterized by the high intake of high-fat products, high-sugar drinks, and excess salt. In animal models of maternal diets containing key components based on the human Western diet, synergistic effects of fat, sugar, and salt on the rise of BP in adult progeny were observed [44-46]. The most frequently used model to induce obesity-related disorders is a high-fat diet [47]. The BP of adult offspring exposed to a maternal high-fat diet varies according to age, sex, diverse 
fatty acid composition, and strain [48-50]. Similarly, the intake of solely a high-fructose diet by rodent mothers results in BP elevation in the offspring [51-53]. A maternal high-fructose diet was developed into an animal model frequently used for studying hypertension and metabolic syndrome of developmental origins [54]. Male rat offspring exposed to a high protein-to-carbohydrate ratio in the maternal diet were also characterized by elevated $\mathrm{BP}$ [55]. In addition, high salt consumption during gestation and lactation has also been associated with hypertension in the offspring in a rat model [40]. However, little is known about the use of large animals to evaluate nutritional programming-induced hypertension.

Worthy of note is that nutritional programming can also be advantageous. Several nutritional interventions have proven to be effective in preventing the development of many adult diseases, including hypertension, with the use of animal models [56]. Since all nutrients during pregnancy play a crucial role in fetal growth and development, studies utilizing animal models of nutritional programming will lead to a better understanding of the timing, optimal dose, and intake duration of nutritional interventions for clinical practice.

\subsection{Maternal Illnesses and Conditions}

Maternal illnesses and complications during pregnancy can cause fetal programming and increase the risk of developing hypertension in offspring. Thus, animal models that mimic chronic illnesses and pregnancy complications have been established to study hypertension of developmental origins. Table 1 shows that rats are the most commonly used animal species. Diverse animal models resembling human illnesses and pregnancy complications have been evaluated, such as hypertensive disorders of pregnancy $[57,58]$, preeclampsia [59-61], chronic kidney disease [62], diabetes [63,64], polycystic ovary syndrome [65], maternal inflammation [66,67], maternal hypoxia [68,69], and sleep disorder $[70,71]$.

Hypertensive disorders affect around $10 \%$ of pregnancies, which includes the 3-5\% of all pregnancies complicated by preeclampsia [72]. A previous cohort study showed that there is an association between maternal hypertension and adverse cardiometabolic outcomes in offspring at 40 years of age, including a $67 \%$ increased risk of hypertension [73]. Studies in two animal models-spontaneously hypertensive rat (SHR) and renovascular hypertensive rat-support an association between maternal hypertension and rising $\mathrm{BP}$ in the offspring during young adulthood [57,58]. Several animal models have been established that mimic changes in maternal preeclampsia. For example, pregnant rats were administered suramin [59] or $\mathrm{N}^{\mathrm{G}}$-nitro-L-arginine-methyl ester (L-NAME, an inhibitor of nitric oxide synthase) [60], or underwent a reduced uterine perfusion procedure [61], resulting in elevated BP in their adult offspring. Pregnant women with chronic kidney disease (CKD) are at risk of adverse outcomes for themselves and their offspring [74]. An adenine-induced maternal CKD model was used to study uremia-related adverse outcomes in pregnancy and offspring, including hypertension of developmental origins [59].

Epidemiological observations have established that exposure to gestational diabetes mellitus in utero leads to a high risk of high BP in childhood [75,76]. Hypertension in offspring induced by maternal diabetes is also demonstrable in animal models $[63,64]$. Although many models have been used for diabetes research [77], only streptozotocin (STZ)induced diabetes has been modelled for hypertension of developmental origins [63,64]. Both type 1 and type 2 diabetes can be induced by STZ when given to adult [63,64] or neonate rats [63]. Another common pregnancy complication is iron-deficiency anemia. A previous report demonstrated that adult offspring of both sexes in a rat model of maternal iron deficiency had hypertension at 16 weeks of age [36].

Additionally, polycystic ovary syndrome (PCOS), inflammatory disorders, and hypoxia are associated with an increased risk of maternal pregnancy complications [78,79]. In the case of PCOS, the fetus is exposed to high levels of testosterone from the maternal circulation [80]. Thus, a model of maternal hyperandrogenemia by testosterone cypionate administration in pregnant rats in late gestation was developed to study BP in adult offspring [65]. As a result, female offspring exposed to prenatal androgen de- 
veloped hypertension at 120 days of age [65]. Prenatal exposure to two pyrogens, LPS and zymosan, has been used to mimic maternal inflammation, and both models showed elevated BP in adult offspring $[66,67]$. Likewise, hypertension can be programmed by prenatal hypoxia in rats [68] or sheep [69]. Moreover, sleep disorders or chronodisruption in pregnant women could have harmful consequences for their offspring, as we reviewed elsewhere [81]. Table 1 shows that adult rat offspring exposed to maternal sleep restriction or constant light prenatally were found to develop hypertension [70,71]. Based on evidence gathered from the above-mentioned studies, various maternal illnesses and conditions indeed impact the offspring's BP and validate the epidemiological observations. However, whether other maternal conditions such as depression are relevant to the developmental programming of hypertension has not yet been adequately addressed.

It is noteworthy that most animal models employ rats and may evaluate short-term but not long-term outcomes in offspring. Research on $\mathrm{DOHaD}$ should now be intensified to validate the observed effects, with long-term follow-up studies using different species to identify the underlying common mechanisms.

\subsection{Chemical and Medication Exposure}

In addition to maternal conditions, early-life chemical and medication exposure has been associated with the developmental programming of hypertension. Table 2 illustrates that prenatal exposure to 2,3,7,8-tetrachlorodibenzo-p-dioxin (TCDD) or bisphenol A leads to increased BP in adult rat offspring [82-84]. These findings support the epidemiological data indicating that exposure to environmental chemicals such as endocrine-disrupting chemicals (EDCs) during critical developmental stages can increase the risk of cardiovascular disease later in life [85].

Substance abuse is also a major maternal insult; about $6-16 \%$ of pregnant women in the United States are alcohol users, cigarette smokers, or illicit drug users [86]. Previous reports on animal models demonstrated that maternal nicotine, alcohol, or caffeine exposure caused elevated BP in rat offspring [87-89]. However, similar models using large animals are not applied at the present time.

Additionally, medication use during pregnancy is also involved in the pathogenesis of programmed hypertension. As shown in Table 2, cyclosporine [90], gentamicin [91], minocycline [92], tenofovir [93], or glucocorticoid [94-98] administration in critical periods of development has been reported to induce hypertension of developmental origins in offspring. Unlike in humans, renal development in rodents continues up to postnatal week $1-2$. Thus, adverse events during gestation and the early lactation period can impair nephrogenesis and reduce nephron numbers, resulting in hypertension in later life [99]. Cyclosporine, gentamicin, and glucocorticoid have been related to renal programming and reduced nephron numbers in various animal models [99]. Particularly noteworthy is glucocorticoid, the most extensively studied medication in animal models of programmed hypertension. A developing fetus is prone to being exposed to excessive glucocorticoids through excess maternal corticosteroid use (e.g., due to a stressed pregnancy) or through exogenous administration (e.g., during preterm birth). In rats, both maternal and neonatal administration of dexamethasone induced hypertension in adult offspring [94-96]. Likewise, prenatal glucocorticoid administration in a sheep model caused increased BP in the offspring $[97,98]$. Moreover, the use of minocycline, a tetracycline antibiotic, during pregnancy and lactation was shown to induce programmed hypertension in rat offspring, coinciding with alterations of the gut microbiota and its derived metabolites [92]. Tenofovir, an antiviral drug, can also program hypertension in a rat model [93]. To sum up, different classes of medications contribute to developmental programming of hypertension. It is possible that various insults can cause similar adult phenotypes that converge on common mechanisms, culminating in the development of hypertension. 
Table 1. Summary of animal models of the developmental programming of hypertension, categorized according to maternal illness and pregnancy complications.

\begin{tabular}{|c|c|c|c|c|}
\hline Maternal Illnesses and Conditions & Animal Models & Species/Gender & Age at Hypertension Development & Ref. \\
\hline \multirow[t]{2}{*}{ Hypertensive disorders of pregnancy } & Genetic hypertension model & SHR/M & 12 weeks & [57] \\
\hline & 2-kidney, 1-clip renovascular hypertension model & $\mathrm{SD}$ rat $/ \mathrm{M}, \mathrm{F}$ & 16 weeks & [58] \\
\hline \multirow[t]{2}{*}{ Preeclampsia } & Intraperitoneal administration of $60 \mathrm{mg} / \mathrm{kg}$ suramin on gestational days 10 and 11 & $\mathrm{SD}$ rat/M & 12 weeks & [59] \\
\hline & Subcutaneous administration of $60 \mathrm{mg} / \mathrm{kg}$ L-NAME during pregnancy & $\mathrm{SD}$ rat/M & 12 weeks & [60] \\
\hline Chronic kidney disease & $\begin{array}{c}\begin{array}{c}0.5 \% \text { adenine supplementation from } 3 \text { weeks before pregnancy until } 3 \text { weeks after } \\
\text { delivery }\end{array}\end{array}$ & $\mathrm{SD}$ rat $/ \mathrm{M}$ & 12 weeks & [62] \\
\hline \multirow[t]{2}{*}{ Type 1 diabetes } & Single intraperitoneal injection of $45 \mathrm{mg} / \mathrm{kg}$ STZ on gestational day 0 & $\mathrm{SD}$ rat/M & 12 weeks & [63] \\
\hline & Single intraperitoneal injection of $35 \mathrm{mg} / \mathrm{kg}$ STZ on gestational day 0 & $\mathrm{SD} \mathrm{rat} / \mathrm{M}$ & 6 months & [64] \\
\hline Type 2 diabetes & $\begin{array}{c}\text { Mother rat received single intraperitoneal injection of } 50 \mathrm{mg} / \mathrm{kg} \text { STZ at newborn } \\
\text { stage }\end{array}$ & $\mathrm{SD}$ rat $/ \mathrm{M}$ & 12 weeks & {$[63]$} \\
\hline Anemia & Iron-deficiency diet from 4 weeks before pregnancy until delivery & Rowett hooded Lister rat/M \& F & 16 weeks & [36] \\
\hline Polycystic ovary syndrome & Subcutaneous injection of $5 \mathrm{mg} / \mathrm{kg}$ testosterone cypionate on gestational day 20 & Wistar rat/F & 120 days & [65] \\
\hline \multirow[t]{2}{*}{ Maternal inflammation } & Intraperitoneal administration of $0.79 \mathrm{mg} / \mathrm{kg}$ LPS on gestational days 8,10 , and 12 & $\mathrm{SD}$ rat/M \& F & 12 weeks & [66] \\
\hline & Intraperitoneal injection of $2.37 \mathrm{mg} / \mathrm{kg}$ zymosan on gestation days 8,10 , and 12 & $\mathrm{SD} \mathrm{rat} / \mathrm{M}$ & 66 weeks & [67] \\
\hline \multirow[t]{2}{*}{ Maternal hypoxia } & $\begin{array}{l}\text { Hypoxia maintained at constant inspired fraction of oxygen of } 13 \% \text { from } \\
\text { gestational day } 6 \text { to } 20\end{array}$ & Wistar rat/M & 4 months & [68] \\
\hline & Hypoxia maintained at 10\% oxygen from gestational day 105 to 145 & Sheep/F & 9 months & [69] \\
\hline \multirow[t]{2}{*}{ Sleep disorder } & Sleep restriction & Wistar rat/M & 3 months & [70] \\
\hline & $24 \mathrm{~h}$ constant light exposure during pregnancy & $\mathrm{SD}$ rat/M & 12 weeks & [71] \\
\hline
\end{tabular}

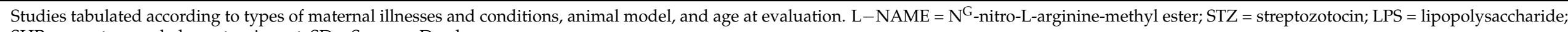
$\mathrm{SHR}=$ spontaneously hypertensive rat; $\mathrm{SD}=$ Sprague-Dawley. 
Table 2. Summary of animal models of the developmental programming of hypertension, categorized according to chemical and medication exposure.

\begin{tabular}{|c|c|c|c|c|}
\hline Chemical or Medication & Animal Models & Species/Gender & Age at Hypertension Development & Ref. \\
\hline \multirow[t]{2}{*}{ TCDD } & Oral administration of $200 \mathrm{ng} / \mathrm{kg}$ TCDD on gestational days 14 and 21 and postnatal days 7 and 14 & $\mathrm{SD}$ rat/M & 12 weeks & [82] \\
\hline & Oral administration of $200 \mathrm{ng} / \mathrm{kg}$ TCDD on gestational days 14 and 21 and postnatal days 7 and 14 & $\mathrm{SD}$ rat/M & 16 weeks & [83] \\
\hline Bisphenol A & Oral administration of $50 \mu \mathrm{g} / \mathrm{kg} /$ day bisphenol A during pregnancy and lactation & $\mathrm{SD}$ rat/M & 16 weeks & [84] \\
\hline Nicotine & Nicotine administration via osmotic mini-pump at $4 \mu \mathrm{g} / \mathrm{kg} / \mathrm{min}$ from gestational day 4 to postnatal day 10 & $\mathrm{SD}$ rat/M & 8 months & [87] \\
\hline Caffeine & Subcutaneous injection of $20 \mathrm{mg} / \mathrm{kg}$ caffeine daily during pregnancy & C57BL/6 mouse/M & 3 months & [89] \\
\hline Cyclosporine & Cyclosporine $3.3 \mathrm{mg} / \mathrm{kg}$ from gestational day 10 to postnatal day 7 & $\mathrm{SD}$ rat $/ \mathrm{M}$ & 11 weeks & [90] \\
\hline Gentamicin & Subcutaneous injection of $110 \mathrm{mg} / \mathrm{kg}$ gentamicin from gestational day 10 to 15 or 15 to 20 & $\mathrm{SD}$ rat/F & 1 year & [91] \\
\hline Minocycline & Minocycline $50 \mathrm{mg} / \mathrm{kg}$ via oral gavage during pregnancy and lactation & $\mathrm{SD}$ rat/M & 12 weeks & [92] \\
\hline Tenofovir & Tenofovir $100 \mathrm{mg} / \mathrm{kg}$ diet from 1 week before mating and during pregnancy & Wistar rat/M & 6 months & [93] \\
\hline \multirow{4}{*}{ Glucocorticoid } & Intraperitoneal injection of $0.1 \mathrm{mg} / \mathrm{kg}$ dexamethasone from gestational day 16 to 22 & $\mathrm{SD}$ rat $/ \mathrm{M}$ & 12 weeks & [95] \\
\hline & $\begin{array}{l}\text { Intraperitoneal injection of } 0.5 \mathrm{mg} / \mathrm{kg} \text { dexamethasone on postnatal day } 1,0.3 \mathrm{mg} / \mathrm{kg} \text { on day } 2 \text {, and } \\
0.1 \mathrm{mg} / \mathrm{kg} \text { on day } 3 .\end{array}$ & $\mathrm{SD}$ rat $/ \mathrm{M}$ & 12 weeks & [96] \\
\hline & Intramuscular injection of $0.17 \mathrm{mg} / \mathrm{kg}$ betamethasone on gestational days 80 and 81 & Sheep/M,F & 18 months & [97] \\
\hline & Intravenous treatment with $0.48 \mathrm{mg} / \mathrm{h}$ dexamethasone for $48 \mathrm{~h}$ on gestational day 27 & Sheep/M,F & 16 months & [98] \\
\hline
\end{tabular}

Studies tabulated according to type of chemical or medication, animal model, and age at evaluation. TCDD = 2,3,7,8-tetrachlorodibenzo-p-dioxin; SD = Sprague-Dawley. 
Emerging evidence supports a "two-hit" hypothesis that explains the developmental programming of adult diseases [8]. Hypertension can develop with two sequential hits, the first hit being the response to a prenatal insult, followed by the second hit in response to ongoing programming induced by the first hit. During fetal development, the first hit can lead to morphological changes and functional adaption of vital organ systems, which alone is not sufficient to alter the adult phenotype. Another type of insult may act as a second hit, during which the same mechanism is targeted and could unmask or amplify the underlying defects culminating in a disease state. Accordingly, a number of two-hit models have been used to evaluate whether two distinct hits affect offspring outcomes synergistically or differently when combined as compared to either hit alone. For example, models of a highfructose diet and TCDD exposure [82], TCDD plus dexamethasone exposure [83], combined bisphenol A and a high-fat diet [84], and a high-fructose diet plus a post-weaning high-fat diet [100] have been established to study hypertension of developmental origins. Together, these animal models have provided evidence of a number of common mechanisms behind hypertension of developmental origins, which will be discussed in turn.

\section{Common Mechanisms Underlying Hypertension of Developmental Origins}

In view of the fact that diverse early-life insults create very similar outcomes in adult offspring, there might be some common mechanistic pathways contributing to the pathogenesis of hypertension of developmental origins. So far, the proposed mechanisms include oxidative stress, aberrant RAS, reduced nephron numbers, gut microbiota dysbiosis, and sex differences [10,18-21].

\subsection{Oxidative Stress}

During fetal development, overproduction of reactive oxygen species (ROS) under adverse conditions in utero prevails over the defensive antioxidant system, resulting in oxidative stress damage [101]. There are several types of early-life insults linked to oxidative stress in mediating hypertension of developmental origins, including maternal caloric restriction [28,29], a zinc-deficient diet [37], a methyl-donor diet [39], high fat intake [50], high-fructose consumption [51], preeclampsia [60,61], maternal CKD [62], gestational diabetes [63], maternal hypoxia [68,69], TCDD exposure [83], bisphenol A exposure [84], nicotine exposure [87], and glucocorticoid use [94].

Reported mechanisms behind oxidative stress-induced hypertension of developmental origins consist of increased ROS generation [61], decreased antioxidant capacity [35], impaired nitric oxide (NO) signaling pathway $[33,59,62,94]$, and increased oxidative damage $[29,82,84,94]$. Markers of lipid peroxidation such as malondialdehyde (MDA) and F2-isoprostanes were proven to be elevated in animal models of programmed hypertension induced by a maternal low-protein diet [35], maternal L-NAME administration [60], and reduced uterine perfusion [61]. Additionally, the expression of 8-hydroxydeoxyguanosine (8-OHdG), an oxidative DNA damage marker, was increased in animal models of hypertension programmed by a maternal methyl-donor diet [39], prenatal dexamethasone plus TCDD exposure [82], combined high-fat diet and bisphenol A exposure [84], prenatal dexamethasone exposure [95], and a maternal high-fructose diet [102].

Conversely, many natural and synthetic antioxidants have been used as a reprogramming strategy to prevent hypertension of developmental origins in diverse of animal models $[20,103]$. These observations suggest the notion that the developmental programming of hypertension might be driven by oxidative stress.

\subsection{Aberrant Renin-Angiotensin System}

Blood pressure is tightly controlled by the renin-angiotensin system (RAS) [104]. The blockade of the RAS provides the rationale for current antihypertensive therapies. The kidney is a major target for all components of the RAS. During kidney development, constituents of the RAS are highly expressed and play key roles in mediating proper renal morphology and physiological function [105]. In humans, RAS blockers have been avoided 
for pregnant women due to fetopathy and renal maldevelopment [106]. The adult progeny of animals that are transgenic for RAS genes or received angiotensin receptor blocker (ARB) during the nephrogenesis stage to block the RAS have a concurrent reduction in nephron numbers and hypertension $[107,108]$.

An increasing number of animal models related to aberrant RAS are now being developed to evaluate hypertension of developmental programming [109]. Various nutritional insults can program the kidney and RAS concurrently - protein restriction [34], calorie restriction [30], a high-fructose diet [51], and a high-fat diet [110]—resulting in hypertension in adult offspring.

Adult rat offspring of diabetic mothers developed hypertension coinciding with increased angiotensin-converting enzyme (ACE) activity [111]. Other maternal illnesses and conditions such as hypertension [58], CKD [62], chronodisruption [78], and preeclampsia [60] also interfere with aberrant RAS and programmed hypertension. Moreover, programmed hypertension coinciding with dysregulated RAS can be triggered by maternal exposure to TCDD [83], caffeine [89], minocycline [92], or glucocorticoid [94,98].

On the other hand, reprogramming strategies targeting the RAS to prevent hypertension of developmental origins have been employed in various animal models [109]. So far, several early-life interventions have been demonstrated, including renin inhibitor [112], ACE inhibitor [113], ARB [114], and ACE2 activator [115]. Overall, the findings suggest that the interplay between the RAS and other mechanisms in early life is implicated in renal programming and consequently, hypertension in adulthood.

\subsection{Reduced Nephron Numbers}

A nephron is the basic unit of the kidney; however, there are large individual differences in the number of nephrons, ranging from 0.25 to 1.1 million per human kidney [116]. Epidemiologic studies have associated low birth weight and prematurity with low nephron numbers as risk factors for hypertension in later life [117]. Reduced nephron numbers can cause compensatory glomerular hyperfiltration and glomerular hypertension, consequently leading to further nephron loss later in life. Therefore, reduced nephron number has been considered as a key mechanism behind renal programming [118]. Likewise, animal studies have indicated that there are vulnerable periods during kidney development that could lead to a reduced nephron endowment.

In rats, adult offspring develop hypertension coinciding with reduced nephron numbers in response to diverse environmental insults during kidney development. These animal models of renal programming involved maternal exposure to cyclosporine [90], gentamicin [91], or glucocorticoid [94], or maternal diabetes [63], a low-protein diet [119], inflammation [120], or hypoxia [121]. However, reduced nephron numbers per se would not be essential for hypertension of developmental origins and renal programming [118]. The role of altering the nephron number in hypertension of developmental origins is still awaiting discovery but is certainly a subject of great interest.

\subsection{Gut Microbiota Dysbiosis}

Recent evidence suggests that early development of the gut microbiota may impact the programming of adult diseases, including hypertension [122,123]. During gestation, dietgut microbiota interactions can alter global histone acetylation and methylation, not only in the mother but also in the fetus via contact with her metabolites [124]. Several mechanisms that link gut microbiota dysbiosis to hypertension have been proposed, including increased sympathetic activity, NO inhibition, aberrant RAS, and altered microbial metabolites, such as short-chain fatty acids (SCFAs) [125].

Data from many animal models indicate that gut microbiota dysbiosis may be involved in the developmental programming of hypertension. Various rat models of maternal insults such as hypertension [57], CKD [62], PCOS [65], TCDD exposure [82], minocycline use [92], a high-fructose diet [102], and a high-fat diet [126] have been examined with regard to the impact of gut microbiota dysbiosis on hypertension of developmental origins. 
Worth noting is the consumption of probiotics or prebiotics, which has become one dietary strategy for modulating the gut microbiota. Our prior studies reported that maternal consumption of a high-fructose or high-fat diet induced hypertension in adult offspring, which can be prevented by modulating the gut microbiota through the intake of prebiotic inulin or probiotic Lactobacillus casei [127,128]. Despite recent studies showing that microbiota-targeted therapies can be applied to various diseases [129], their role in hypertension of developmental origins, especially their use in gestation, awaits further exploration.

\subsection{Sex Differences}

There is a considerable body of literature indicating that sex-dependent differences exist in hypertension of developmental origins [130,131]. It has long been observed that male offspring are more prone to hypertension than female offspring [25,130,131]. Additionally, several mechanisms mentioned above, such as oxidative stress [132], the RAS [133], and gut microbiota [134], are known to respond to environmental stimuli in a sex-specific manner.

Some early-life insults, such as maternal caloric restriction [27], low-protein diet [55], high-fat diet [110], or high-fructose diet [112], or prenatal dexamethasone exposure [135], have been reported to induce hypertension in male but not female offspring. This difference has led many researchers to investigate only males instead of both sexes, as listed in Table 2.

In a prenatal dexamethasone exposure model [135], we found that glucocorticoidprogrammed hypertension developed in male but not in female adult offspring. We also observed the absence of hypertension in female offspring coinciding with lower Agt mRNA expression, suggesting that sex-dependent renal programming within the RAS may underlie the pathogenesis of programmed hypertension. Additionally, we found that the renal transcriptome is sex-specific in hypertension in offspring programmed by a maternal high-fructose diet [112]. One possible protective mechanism of females being refractory to high-fructose-diet-induced programmed hypertension is related to sex differences in the renal transcriptome. However, whether the increased female sensitivity to insult is beneficial or harmful to the developmental programming of various organs in female fetuses remains unclear. Thus, a better understanding of the sex-dependent mechanisms that underlie hypertension of developmental origins will aid in developing a novel sexspecific strategy to prevent programmed hypertension across genders.

\subsection{Others}

Other molecular mechanisms relevant to the developmental programming of hypertension are evaluated in different animal models, such as impaired sodium transport [10], dysregulated nutrient-sensing signaling [136], increased sympathetic nerve activity [137], and epigenetic regulation [138].

These observations suggest that there might be considerable interplay among the common mechanisms behind the pathogenesis of hypertension of developmental origins, even though this remains speculative. Although numerous mechanisms are outlined above, attention will need to be focused on exploring other potential mechanisms and validating them in different types of animal models. A better understanding of the mechanisms behind hypertension of developmental origins is the key to developing novel reprogramming interventions for further clinical translation.

\section{Moving Forward: Promising Prospects of Early-Life Interventions}

Given the advances in our understanding of the $\mathrm{DOHaD}$ research field, it has become apparent that early-life interventions can reprogram molecular mechanisms behind hypertension of developmental origins to prevent the development of hypertension in adulthood. Animal models have been essential in providing ideal reprogramming strategies. As described earlier, many antioxidants have been used as reprogramming strategies to prevent hypertension in offspring in a number of animal models [20,103]: L-arginine [139], L- 
taurine [140], L-citrulline [60], vitamin C [69], vitamin E [28], folic acid [141], selenium [28], melatonin $[39,60,71]$, resveratrol $[83,84,102]$, and $\mathrm{N}$-acetylcysteine [57,59,60,95].

Additionally, several lines of evidence support the idea that early-life interventions targeting specific signaling pathways are of benefit in the prevention of developmental hypertension. First, reprogramming strategies targeting the NO pathway in early life have been employed in various animal models to prevent the development of hypertension in adult progeny. These interventions include supplementation of NO substrate [142], agents that lower asymmetric dimethylarginine (ADMA, an inhibitor of NOS) [95], NO donors [143], and enhancement of NOS expression [144], as reviewed elsewhere [142]. Second, several RAS-based interventions have also shown benefits in protecting against programmed hypertension, such as renin inhibitor, ACEI, ARB, and ACE2 activator [109]. Third, the reprogramming effects of hydrogen sulfide $\left(\mathrm{H}_{2} \mathrm{~S}\right)$-based interventions have been shown in diverse animal models [145]. Currently available reprogramming interventions targeting the $\mathrm{H}_{2} \mathrm{~S}$ pathway are L-cysteine [146], D-cysteine [146], NAC [147], sodium hydrosulfide [148], and garlic [126]. Finally, the targeting of nutrient-sensing signals such as cyclic adenosine monophosphate-activated protein kinase (AMPK) or peroxisome proliferator-activated receptor (PPAR) has been noted to regulate downstream target genes, thereby reprogramming hypertension induced by various maternal insults [149-154]. This review provides a general overview of the various early-life interventions that show benefits with regard to hypertension of developmental origins. Despite the tremendous advances made from animal research, their clinical translation is still a long way off.

\section{Selection of Appropriate Animal Models to Study Hypertension of Developmental Origins}

\subsection{Important Issues for Consideration}

Even though significant advances have been made in developing diverse animal models to study hypertension of developmental origins, the need for meaningful clinical translation remains a research priority. The following conditions should be taken into consideration when we select animal models. First, the timing of the animal's organogenesis is similar to that of humans. Second, the gestation period and litter size should be comparable to those of humans. Third, it is crucial that animal models share similar features of adverse outcomes to those seen in human studies, which can be measured. Finally, any effective therapeutic intervention must be evaluated and validated.

\subsection{Timing of Organogenesis}

Across different species, critical development periods for major organ systems are not uniform. Blood pressure is tightly controlled by coordination among the kidney, heart, brain, and other organ systems. As such, the translatability of studies performed in animals should be approached with caution, as many key stages of BP-controlled organ development that occur before birth in humans occur after birth in some species [103,136,137,155].

Many animal studies on hypertension of developmental origins focus on renal programming [118,137]. Kidney development starts at week 3 and ceases at approximately 36 weeks of gestation in humans [156]. Unlike in humans, rat kidneys continue to develop after birth and complete at 1 to 2 weeks postnatally [157]. Accordingly, adverse environmental conditions during pregnancy as well as lactation can impair kidney development, consequently resulting in hypertension in rodents [118]. For example, repeated dexamethasone administration on embryonic days 15 and 16 [94], from gestational days 16 to 22 [95], or from postnatal days 1 to 3 [96] was associated with developmental programming of hypertension in adult rat offspring.

Another unsolved problem is that almost no studies have taken a comprehensive approach to simultaneously evaluating every BP-controlled organ system in response to in utero exposure at specific developmental stages to assess their relative vulnerability in an experiment. Due to the complex nature of the interplay between organogenesis and environmental insults, the programming effect on various organs might be dissimilar in 
different animal species. Hence, it is apparent that the selected animal paradigm should mirror the timing of human organ development as closely as possible so that the effects of early-life insults can be fully assessed.

\subsection{Gestation Period and Litter Size}

The advantages of a shorter gestation period and higher offspring yield compared to large animal models make rodent models the most commonly used in $\mathrm{DOHaD}$ research. There is a large set of studies on hypertension of developmental origins that were carried out in rats (Tables 1 and 2). The average gestation period for rats is within 23 days, compared to 280 days for humans [158]. If an early-life insult is induced by surgical manipulation or if delivery requires repeated procedures, short gestation in rodents could become disadvantageous. In addition, the short gestation time may not allow for the permanent resolution of developmental plasticity and the identification of critical time periods that are vulnerable to insults.

Unlike humans, rodents generally have more than one offspring, and litter sizes of 8-12 pups are usually seen. Such a large litter size is also a disadvantage when compared to singleton births common in humans and large animal models. Accordingly, normalizing the size of each litter after birth should be considered to control for differences in offspring food intake, maternal care, and pup growth [159]. Since these limitations exist, the complete translation of findings in rodents to human medicine is seriously compromised.

On the other hand, gestational length in sheep is around 150 days, during which the fetal size and development rate are similar to those of humans [160]. With the use of ewe models, maternal caloric restriction [30], maternal hypoxia [69], and prenatal glucocorticoid exposure $[97,98]$ have been shown to cause hypertension in adult progeny. Although these early insults have shown the same adverse effects on offspring BP in sheep and rats, whether different gestation periods and litter sizes differentially impact hypertension of developmental origins in rats and large animals awaits further evaluation.

\subsection{Outcome Measurements}

As we mentioned earlier, rats are the most commonly used species for the developmental programming of hypertension. However, a critical assessment of the data show that this phenomenon is mostly observed when BP is typically measured by the tail cuff method; in contrast, hypertension is not detected in telemetrically instrumented animals [161]. Although BP data obtained from the tail cuff method are reported to correlate well with findings of direct arterial catheter and telemetry methods [162], part of the increased BP in offspring found after early-life insults may be due to an increased stress response related to sympathetic nerve activity.

In adulthood, one rat month is roughly equivalent to three human years [158]. Accordingly, Table 1 lists the timing of hypertension development measured in rats from 12 weeks to 8 months of age, which is equivalent to humans of a specific age group ranging from childhood to early adulthood. Thus, there remain gaps in our knowledge regarding the long-term adverse effects of maternal insults on BP in older adult offspring.

Several species have been studied for cardiovascular outcomes programmed by maternal adverse exposure, including guinea pigs [163], swine [164], and non-human primates [165]. However, none of them have been used to study hypertension of developmental origins. It is important to remember that large animals should not be neglected, as they are generally more physiologically suitable models with regard to human conditions.

In the current review, the wide range of early-life insults certainly influenced the outcomes, resulting in the reported heterogeneity. The results depended strongly on the applied measurement technique and animal model. Methodological heterogeneity is another reason for the observed heterogeneity. A huge percentage of studies employed male-only small animal models with small sample sizes. Future animal studies should improve the methodological quality by applying randomization, blinding, and sample size calculation techniques in order to avoid bias and collect data of better quality. 


\subsection{Effective Interventions}

Currently, reprogramming strategies could be categorized as nutritional intervention, lifestyle modification, or pharmacological therapy. It stands to reason that avoiding in utero exposure to adverse conditions is the most effective strategy for preventing hypertension of developmental origins. Another approach is the use of nutritional intervention during pregnancy and lactation [56]. Although the targeting of specific nutrients as a reprogramming strategy opens a new avenue for prevention [25], there remains a lack of accurate dietary recommendations for specific nutritional requirements for pregnant women in case of deficiencies [166,167].

Research on short-lived rodent models has provided significant results, revealing potential pharmacological therapies for preventing hypertension of developmental origins. However, disparities in the therapeutic doses, timing and duration, and animal models used are among the major concerns. The standardization of animal experiments will improve the comparability of such studies. During the preparation of the current review, we found that almost no studies tested different doses or the use of different species. Additionally, the follow-up period after the cessation of interventions in most cited studies was rather short.

The efficacy of the intervention can be influenced by its duration with respect to organ development in a dose- and species-specific manner. Thus, further translational research into the pharmacokinetics and metabolism of pharmacological intervention is required to validate and compare its safety and therapeutic potential between humans and other species.

\section{Conclusions and Future Perspectives}

Various small (e.g., rat and mouse) and large (e.g., cow and sheep) animal models have made important contributions to the $\mathrm{DOHaD}$ research field, giving rise to convincing evidence of a causal relationship between various early-life insults and the risk of developing hypertension in later life. Our review highlights that animal models are not only used to investigate the mechanisms behind hypertension of developmental origins, but also have an impact on the development of early-life interventions as a reprogramming strategy to prevent the development of hypertension in adulthood.

There are still several questions that need to be answered. In the last decades, many insults have been identified by epidemiological and animal studies. Nevertheless, there is a growing need to identify all factors that can adversely impact the BP of offspring. Additionally, this review did not consider the potential for the programming of hypertension by paternal factors that clearly exist in the $\mathrm{DOHaD}$ field [168]. Moreover, little reliable information currently exists with regard to optimal doses and durations of pharmacological interventions for pregnant women and the long-term effects on their offspring. Currently, preventive strategies should focus on avoiding exposure to theoretically harmful agents perinatally and promoting a healthy lifestyle.

Each of the abovementioned animal models was used to study a specific hypothesis and neither can be considered superior with regard to all aspects of research on hypertension of developmental origins. Therefore, further research is needed to gain a better understanding of the types of early-life insults, other mechanisms behind hypertension of developmental origins, the ideal therapeutic dose and duration of early intervention, and the appropriate animal species. It is proposed that taking a $\mathrm{DOHaD}$ approach with maximum use of the animal evidence should be of benefit in reducing the global burden of hypertension.

Author Contributions: C.-N.H.: contributed to data interpretation, drafting of the manuscript, critical revision of the manuscript, concept generation, and approval of the article; Y.-L.T.: drafting of the manuscript, data interpretation, contributed to concept generation, critical revision of the manuscript, and approval of the article. All authors have read and agreed to the published version of the manuscript. 
Funding: This research was funded by Chang Gung Memorial Hospital, Kaohsiung, Taiwan, grants CMRPG8J0253, CORPG8J0121, CORPG8L0121, CORPG8L0261, and CORPG8L0301.

Institutional Review Board Statement: Not applicable.

Informed Consent Statement: Not applicable.

Data Availability Statement: Data will be available upon request.

Conflicts of Interest: The authors declare no conflict of interest.

\section{References}

1. Barker, D.J. The origins of the developmental origins theory. J. Intern. Med. 2007, 261, 412-417. [CrossRef] [PubMed]

2. Hanson, M. The birth and future health of DOHaD. J. Dev. Orig. Health Dis. 2015, 6, 434-437. [CrossRef] [PubMed]

3. Roseboom, T.; de Rooij, S.; Painter, R. The Dutch famine and its long-term consequences for adult health. Early Hum. Dev. 2006, 82, 485-491. [CrossRef] [PubMed]

4. Hanson, M.; Gluckman, P. Developmental origins of noncommunicable disease: Population and public health implications. Am. J. Clin. Nutr. 2011, 94, 1754S-1758S. [CrossRef]

5. Hales, C.N.; Barker, D.J. The thrifty phenotype hypothesis. Br. Med. Bull. 2001, 60, 5-20. [CrossRef] [PubMed]

6. Wells, J.C. Maternal capital and the metabolic ghetto: An evolutionary perspective on the transgenerational basis of health inequalities. Am. J. Hum. Biol. 2010, 22, 1-17. [CrossRef] [PubMed]

7. Gluckman, P.D.; Hanson, M.A. Living with the past: Evolution, development, and patterns of disease. Science 2004, 305, 1733-1736. [CrossRef]

8. McMullen, S.; Mostyn, A. Animal models for the study of the developmental origins of health and disease. Proc. Nutr. Soc. 2009, 68, 306-320. [CrossRef]

9. McMillen, I.C.; Robinson, J.S. Developmental origins of the metabolic syndrome: Prediction, plasticity, and programming. Physiol Rev. 2005, 85, 571-633. [CrossRef] [PubMed]

10. Ojeda, N.B.; Grigore, D.; Alexander, B.T. Developmental programming of hypertension: Insight from animal models of nutritional manipulation. Hypertension 2008, 52, 44-50. [CrossRef] [PubMed]

11. Bromfield, S.; Muntner, P. High blood pressure: The leading global burden of disease risk factor and the need for worldwide prevention programs. Curr. Hypertens. Rep. 2013, 15, 134-136. [CrossRef] [PubMed]

12. World Health Organization. Hypertension. 2019. Available online: https://www.who.int/news-room/fact-sheets/detail/ hypertension (accessed on 13 April 2021).

13. Lerman, L.O.; Kurtz, T.W.; Touyz, R.M.; Ellison, D.H.; Chade, A.R.; Crowley, S.D.; Mattson, D.L.; Mullins, J.J.; Osborn, J.; Eirin, A.; et al. Animal Models of Hypertension: A Scientific Statement From the American Heart Association. Hypertension 2019, 73, e87-e120. [CrossRef] [PubMed]

14. Pinto, Y.M.; Paul, M.; Ganten, D. Lessons from rat models of hypertension: From Goldblatt to genetic engineering. Cardiovasc. Res. 1998, 39, 77-88. [CrossRef]

15. Oparil, S.; Schmieder, R.E. New approaches in the treatment of hypertension. Circ. Res. 2015, 116, 1074-1095. [CrossRef] [PubMed]

16. Mills, K.T.; Bundy, J.D.; Kelly, T.N.; Reed, J.E.; Kearney, P.M.; Reynolds, K.; Chen, J.; He, J. Global Disparities of Hypertension Prevalence and Control: A Systematic Analysis of Population-Based Studies From 90 Countries. Circulation 2016, 134, 441-450. [CrossRef] [PubMed]

17. Bagby, S.P. Maternal nutrition, low nephron number, and hypertension in later life: Pathways of nutritional programming. J. Nutr. 2007, 137, 1066-1072. [CrossRef] [PubMed]

18. Chong, E.; Yosypiv, I.V. Developmental programming of hypertension and kidney disease. Int. J. Nephrol. 2012, $2012,760580$. [CrossRef] [PubMed]

19. Paixão, A.D.; Alexander, B.T. How the kidney is impacted by the perinatal maternal environment to develop hypertension. Biol. Reprod. 2013, 89, 144. [CrossRef]

20. Hsu, C.N.; Tain, Y.L. Early Origins of Hypertension: Should Prevention Start Before Birth Using Natural Antioxidants? Antioxidants 2020, 9, 1034. [CrossRef] [PubMed]

21. Tain, Y.L.; Joles, J.A. Reprogramming: A Preventive Strategy in Hypertension Focusing on the Kidney. Int. J. Mol. Sci. 2015, 17, 23. [CrossRef]

22. Chavatte-Palmer, P.; Tarrade, A.; Rousseau-Ralliard, D. Diet before and during Pregnancy and Offspring Health: The Importance of Animal Models and What Can Be Learned from Them. Int. J. Environ. Res. Public Health 2016, 13, 586. [CrossRef]

23. Furukawa, S.; Kuroda, Y.; Sugiyama, A. A comparison of the histological structure of the placenta in experimental animals. J. Toxicol. Pathol. 2014, 27, 11-18. [CrossRef]

24. Morel, O.; Laporte-Broux, B.; Tarrade, A.; Chavatte-Palmer, P. The use of ruminant models in biomedical perinatal research. Theriogenology 2012, 78, 1763-1773. [CrossRef] [PubMed]

25. Hsu, C.N.; Tain, Y.L. The Double-Edged Sword Effects of Maternal Nutrition in the Developmental Programming of Hypertension. Nutrients 2018, 10, 1917. [CrossRef] [PubMed] 
26. Ozaki, T.; Nishina, H.; Hanson, M.A.; Poston, L. Dietary restriction in pregnant rats causes gender-related hypertension and vascular dysfunction in offspring. J. Physiol. 2001, 530, 141-152. [CrossRef] [PubMed]

27. Franco Mdo, C.; Ponzio, B.F.; Gomes, G.N.; Gil, F.Z.; Tostes, R.; Carvalho, M.H.; Fortes, Z.B. Micronutrient prenatal supplementation prevents the development of hypertension and vascular endothelial damage induced by intrauterine malnutrition. Life Sci. 2009, 85, 327-333. [CrossRef] [PubMed]

28. Tain, Y.L.; Hsieh, C.S.; Lin, I.C.; Chen, C.C.; Sheen, J.M.; Huang, L.T. Effects of maternal L-citrulline supplementation on renal function and blood pressure in offspring exposed to maternal caloric restriction: The impact of nitric oxide pathway. Nitric. Oxide. 2010, 23, 34-41. [CrossRef] [PubMed]

29. Gilbert, J.S.; Lang, A.L.; Grant, A.R.; Nijland, M.J. Maternal nutrient restriction in sheep: Hypertension and decreased nephron number in offspring at 9 months of age. J. Physiol. 2005, 565, 137-147. [CrossRef] [PubMed]

30. Gopalakrishnan, G.S.; Gardner, D.S.; Rhind, S.M.; Rae, M.T.; Kyle, C.E.; Brooks, A.N.; Walker, R.M.; Ramsay, M.M.; Keisler, D.H.; Stephenson, T.; et al. Programming of adult cardiovascular function after early maternal undernutrition in sheep. Am. J. Physiol. Regul. Integr. Comp. Physiol. 2004, 287, R12-R20. [CrossRef] [PubMed]

31. Mossa, F.; Carter, F.; Walsh, S.W.; Kenny, D.A.; Smith, G.W.; Ireland, J.L.; Hildebrandt, T.B.; Lonergan, P.; Ireland, J.J.; Evans, A.C. Maternal undernutrition in cows impairs ovarian and cardiovascular systems in their offspring. Biol. Reprod. 2013, 88, 92. [CrossRef] [PubMed]

32. Zohdi, V.; Lim, K.; Pearson, J.T.; Black, M.J. Developmental programming of cardiovascular disease following intrauterine growth restriction: Findings utilising a rat model of maternal protein restriction. Nutrients 2014, 7, 119-152. [CrossRef] [PubMed]

33. Sathishkumar, K.; Elkins, R.; Yallampalli, U.; Yallampalli, C. Protein restriction during pregnancy induces hypertension and impairs endothelium-dependent vascular function in adult female offspring. J. Vasc. Res. 2009, 46, 229-239. [CrossRef] [PubMed]

34. Woods, L.L.; Ingelfinger, J.R.; Nyengaard, J.R.; Rasch, R. Maternal protein restriction suppresses the newborn renin-angiotensin system and programs adult hypertension in rats. Pediatr. Res. 2001, 49, 460-467. [CrossRef] [PubMed]

35. Cambonie, G.; Comte, B.; Yzydorczyk, C.; Ntimbane, T.; Germain, N.; Lê, N.L.; Pladys, P.; Gauthier, C.; Lahaie, I.; Abran, D.; et al. Antenatal antioxidant prevents adult hypertension, vascular dysfunction, and microvascular rarefaction associated with in utero exposure to a low-protein diet. Am. J. Physiol. Regul. Integr. Comp. Physiol. 2007, 292, R1236-R1245. [CrossRef] [PubMed]

36. Gambling, L.; Dunford, S.; Wallace, D.I.; Zuur, G.; Solanky, N.; Srai, K.S.; McArdle, H.J. Iron deficiency during pregnancy affects post-natal blood pressure in the rat. J. Physiol. 2003, 552, 603-610. [CrossRef] [PubMed]

37. Tomat, A.; Elesgaray, R.; Zago, V.; Fasoli, H.; Fellet, A.; Balaszczuk, A.M.; Schreier, L.; Costa, M.A.; Arranz, C. Exposure to zinc deficiency in fetal and postnatal life determines nitric oxide system activity and arterial blood pressure levels in adult rats. Br. $J$. Nutr. 2010, 104, 382-389. [CrossRef] [PubMed]

38. Tare, M.; Emmett, S.J.; Coleman, H.A.; Skordilis, C.; Eyles, D.W.; Morley, R.; Parkington, H.C. Vitamin D insufficiency is associated with impaired vascular endothelial and smooth muscle function and hypertension in young rats. J. Physiol. 2011, 589, 4777-4786. [CrossRef] [PubMed]

39. Tain, Y.L.; Chan, J.Y.H.; Lee, C.T.; Hsu, C.N. Maternal melatonin therapy attenuates methyl-donor diet-induced programmed hypertension in male adult rat offspring. Nutrients 2018, 10, 1407. [CrossRef]

40. Koleganova, N.; Piecha, G.; Ritz, E.; Becker, L.E.; Müller, A.; Weckbach, M.; Nyengaard, J.R.; Schirmacher, P.; Gross-Weissmann, M.L. Both high and low maternal salt intake in pregnancy alter kidney development in the offspring. Am. J. Physiol. Renal Physiol. 2011, 301, F344-F354. [CrossRef] [PubMed]

41. Bergel, E.; Belizán, J.M. A deficient maternal calcium intake during pregnancy increases blood pressure of the offspring in adult rats. BJOG 2002, 109, 540-545. [CrossRef]

42. Paixão, A.D.; Maciel, C.R.; Teles, M.B.; Figueiredo-Silva, J. Regional Brazilian diet-induced low birth weight is correlated with changes in renal hemodynamics and glomerular morphometry in adult age. Biol. Neonate 2001, 80, 239-246. [CrossRef] [PubMed]

43. Vieira-Filho, L.D.; Cabral, E.V.; Farias, J.S.; Silva, P.A.; Muzi-Filho, H.; Vieyra, A.; Paixão, A.D. Renal molecular mechanisms underlying altered $\mathrm{Na}+$ handling and genesis of hypertension during adulthood in prenatally undernourished rats. Br. J. Nutr. 2014, 111, 1932-1944. [CrossRef] [PubMed]

44. Yamada-Obara, N.; Yamagishi, S.I.; Taguchi, K.; Kaida, Y.; Yokoro, M.; Nakayama, Y.; Ando, R.; Asanuma, K.; Matsui, T.; Ueda, S.; et al. Maternal exposure to high-fat and high-fructose diet evokes hypoadiponectinemia and kidney injury in rat offspring. Clin. Exp. Nephrol. 2016, 20, 853-886. [CrossRef] [PubMed]

45. Tain, Y.L.; Lee, W.C.; Leu, S.; Wu, K.; Chan, J. High salt exacerbates programmed hypertension in maternal fructose-fed male offspring. Nutr. Metab. Cardiovasc. Dis. 2015, 25, 1146-1151. [CrossRef]

46. Tain, Y.L.; Wu, K.L.H.; Lee, W.C.; Leu, S.; Chan, J.Y.H. Prenatal Metformin Therapy Attenuates Hypertension of Developmental Origin in Male Adult Offspring Exposed to Maternal High-Fructose and Post-Weaning High-Fat Diets. Int. J. Mol. Sci. 2018, 19, 1066. [CrossRef] [PubMed]

47. Buettner, R.; Schölmerich, J.; Bollheimer, L.C. High-fat diets: Modeling the metabolic disorders of human obesity in rodents. Obesity 2007, 15, 798-808. [CrossRef] [PubMed]

48. Williams, L.; Seki, Y.; Vuguin, P.M.; Charron, M.J. Animal models of in utero exposure to a high fat diet: A review. Biochim. Biophys. Acta 2014, 1842, 507-519. [CrossRef] [PubMed] 
49. Tain, Y.L.; Lin, Y.J.; Sheen, J.M.; Yu, H.R.; Tiao, M.M.; Chen, C.C.; Tsai, C.C.; Huang, L.T.; Hsu, C.N. High fat diets sex-specifically affect the renal transcriptome and program obesity, kidney injury, and hypertension in the offspring. Nutrients 2017, 9, 357. [CrossRef] [PubMed]

50. Resende, A.C.; Emiliano, A.F.; Cordeiro, V.S.; de Bem, G.F.; de Cavalho, L.C.; de Oliveira, P.R.; Neto, M.L.; Costa, C.A.; Boaventura, G.T.; de Moura, R.S. Grape skin extract protects against programmed changes in the adult rat offspring caused by maternal high-fat diet during lactation. J. Nutr. Biochem. 2013, 24, 2119-2126. [CrossRef]

51. Tain, Y.L.; Wu, K.L.; Lee, W.C.; Leu, S.; Chan, J.Y. Maternal fructose-intake-induced renal programming in adult male offspring. J. Nutr. Biochem. 2015, 26, 642-650. [CrossRef] [PubMed]

52. Tain, Y.L.; Chan, J.Y.; Hsu, C.N. Maternal Fructose Intake Affects Transcriptome Changes and Programmed Hypertension in Offspring in Later Life. Nutrients 2016, 8, 757. [CrossRef]

53. Seong, H.Y.; Cho, H.M.; Kim, M.; Kim, I. Maternal High-Fructose Intake Induces Multigenerational Activation of the ReninAngiotensin-Aldosterone System. Hypertension 2019, 74, 518-525. [CrossRef] [PubMed]

54. Lee, W.C.; Wu, K.L.H.; Leu, S.; Tain, Y.L. Translational insights on developmental origins of metabolic syndrome: Focus on fructose consumption. Biomed. J. 2018, 41, 96-101. [CrossRef] [PubMed]

55. Thone-Reineke, C.; Kalk, P.; Dorn, M.; Klaus, S.; Simon, K.; Pfab, T.; Godes, M.; Persson, P.; Unger, T.; Hocher, B. High-protein nutrition during pregnancy and lactation programs blood pressure, food efficiency, and body weight of the offspring in a sex-dependent manner. Am. J. Physiol. Regul. Integr. Comp. Physiol. 2006, 291, R1025-R1030. [CrossRef] [PubMed]

56. Hsu, C.N.; Tain, Y.L. The Good, the Bad, and the Ugly of Pregnancy Nutrients and Developmental Programming of Adult Disease. Nutrients 2019, 11, 894. [CrossRef] [PubMed]

57. Hsu, C.N.; Hou, C.Y.; Chang-Chien, G.P.; Lin, S.; Tain, Y.L. Maternal N-Acetylcysteine Therapy Prevents Hypertension in Spontaneously Hypertensive Rat Offspring: Implications of Hydrogen Sulfide-Generating Pathway and Gut Microbiota. Antioxidants 2020, 9, 856. [CrossRef] [PubMed]

58. Guo, Q.; Feng, X.; Xue, H.; Jin, S.; Teng, X.; Duan, X.; Xiao, L.; Wu, Y. Parental Renovascular Hypertension-Induced Autonomic Dysfunction in Male Offspring Is Improved by Prenatal or Postnatal Treatment With Hydrogen Sulfide. Front. Physiol. 2019, 10, 1184. [CrossRef] [PubMed]

59. Tain, Y.L.; Hsu, C.N.; Lee, C.T.; Lin, Y.J.; Tsai, C.C. N-Acetylcysteine Prevents Programmed Hypertension in Male Rat Offspring Born to Suramin-Treated Mothers. Biol. Reprod. 2016, 95, 8. [CrossRef] [PubMed]

60. Tain, Y.L.; Lee, C.T.; Chan, J.Y.; Hsu, C.N. Maternal melatonin or N-acetylcysteine therapy regulates hydrogen sulfide-generating pathway and renal transcriptome to prevent prenatal N(G)-Nitro-L-arginine methyl ester (L-NAME)-induced fetal programming of hypertension in adult male offspring. Am. J. Obstet. Gynecol. 2016, 215, 636. [CrossRef]

61. Ojeda, N.B.; Hennington, B.S.; Williamson, D.T.; Hill, M.L.; Betson, N.E.; Sartori-Valinotti, J.C.; Reckelhoff, J.F.; Royals, T.P.; Alexander, B.T. Oxidative stress contributes to sex differences in blood pressure in adult growth-restricted offspring. Hypertension 2012, 60, 114-122. [CrossRef] [PubMed]

62. Hsu, C.N.; Yang, H.W.; Hou, C.Y.; Chang-Chien, G.P.; Lin, S.; Tain, Y.L. Maternal Adenine-Induced Chronic Kidney Disease Programs Hypertension in Adult Male Rat Offspring: Implications of Nitric Oxide and Gut Microbiome Derived Metabolites. Int. J. Mol. Sci. 2020, 21, 7237. [CrossRef] [PubMed]

63. Tain, Y.L.; Lee, W.C.; Hsu, C.N.; Lee, W.C.; Huang, L.T.; Lee, C.T.; Lin, C.Y. Asymmetric dimethylarginine is associated with developmental programming of adult kidney disease and hypertension in offspring of streptozotocin-treated mothers. PLoS ONE 2013, 8, e55420. [CrossRef] [PubMed]

64. Dib, A.; Payen, C.; Bourreau, J.; Munier, M.; Grimaud, L.; Fajloun, Z.; Loufrani, L.; Henrion, D.; Fassot, C. In Utero Exposure to Maternal Diabetes Is Associated With Early Abnormal Vascular Structure in Offspring. Front. Physiol. 2018, 9, 350. [CrossRef]

65. Sherman, S.B.; Sarsour, N.; Salehi, M.; Schroering, A.; Mell, B.; Joe, B.; Hill, J.W. Prenatal androgen exposure causes hypertension and gut microbiota dysbiosis. Gut Microbes 2018, 9, 400-421. [CrossRef] [PubMed]

66. Wang, J.; Yin, N.; Deng, Y.; Wei, Y.; Huang, Y.; Pu, X.; Li, L.; Zheng, Y.; Guo, J.; Yu, J.; et al. Ascorbic Acid Protects against Hypertension through Downregulation of ACE1 Gene Expression Mediated by Histone Deacetylation in Prenatal InflammationInduced Offspring. Sci. Rep. 2016, 6, 39469. [CrossRef] [PubMed]

67. Liao, W.; Wei, Y.; Yu, C.; Zhou, J.; Li, S.; Pang, Y.; Li, G.; Li, X. Prenatal exposure to zymosan results in hypertension in adult offspring rats. Clin. Exp. Pharmacol. Physiol. 2008, 35, 1413-1418. [CrossRef]

68. Giussani, D.A.; Camm, E.J.; Niu, Y.; Richter, H.G.; Blanco, C.E.; Gottschalk, R.; Blake, E.Z.; Horder, K.A.; Thakor, A.S.; Hansell, J.A.; et al. Developmental programming of cardiovascular dysfunction by prenatal hypoxia and oxidative stress. PLoS ONE 2012, 7, e31017. [CrossRef] [PubMed]

69. Brain, K.L.; Allison, B.J.; Niu, Y.; Cross, C.M.; Itani, N.; Kane, A.D.; Herrera, E.A.; Skeffington, K.L.; Botting, K.J.; Giussani, D.A. Intervention against hypertension in the next generation programmed by developmental hypoxia. PLoS Biol. 2019, 17, e2006552. [CrossRef] [PubMed]

70. Thomal, J.T.; Palma, B.D.; Ponzio, B.F.; Franco Mdo, C.; Zaladek-Gil, F.; Fortes, Z.B.; Tufik, S.; Gomes, G.N. Sleep restriction during pregnancy: Hypertension and renal abnormalities in young offspring rats. Sleep 2010, 33, 1357-1362. [CrossRef] [PubMed]

71. Tain, Y.L.; Lin, Y.J.; Chan, J.Y.H.; Lee, C.T.; Hsu, C.N. Maternal melatonin or agomelatine therapy prevents programmed hypertension in male offspring of mother exposed to continuous light. Biol. Reprod. 2017, 97, 636-643. [CrossRef] [PubMed] 
72. Fox, R.; Kitt, J.; Leeson, P.; Aye, C.Y.L.; Lewandowski, A.J. Preeclampsia: Risk Factors, Diagnosis, Management, and the Cardiovascular Impact on the Offspring. J. Clin. Med. 2019, 8, 1625. [CrossRef] [PubMed]

73. Kurbasic, A.; Fraser, A.; Mogren, I.; Hallmans, G.; Franks, P.W.; Rich-Edwards, J.W.; Timpka, S. Maternal Hypertensive Disorders of Pregnancy and Offspring Risk of Hypertension: A Population-Based Cohort and Sibling Study. Am. J. Hypertens. 2019, 32, 331-334. [CrossRef] [PubMed]

74. Hladunewich, M.A. Chronic Kidney Disease and Pregnancy. Semin. Nephrol. 2017, 37, 337-346. [CrossRef] [PubMed]

75. Wright, C.S.; Rifas-Shiman, S.L.; Rich-Edwards, J.W.; Taveras, E.M.; Gillman, M.W.; Oken, E. Intrauterine exposure to gestational diabetes, child adiposity, and blood pressure. Am. J. Hypertens. 2009, 22, 215-220. [CrossRef] [PubMed]

76. Lu, J.; Zhang, S.; Li, W.; Leng, J.; Wang, L.; Liu, H.; Li, W.; Zhang, C.; Qi, L.; Tuomilehto, J.; et al. Maternal Gestational Diabetes Is Associated With Offspring's Hypertension. Am. J. Hypertens. 2019, 32, 335-342. [CrossRef] [PubMed]

77. King, A.J. The use of animal models in diabetes research. Br. J. Pharmacol. 2012, 166, 877-894. [CrossRef] [PubMed]

78. Bahri Khomami, M.; Joham, A.E.; Boyle, J.A.; Piltonen, T.; Silagy, M.; Arora, C.; Misso, M.L.; Teede, H.J.; Moran, L.J. Increased maternal pregnancy complications in polycystic ovary syndrome appear to be independent of obesity-A systematic review, meta-analysis, and meta-regression. Obes. Rev. 2019, 20, 659-674. [CrossRef] [PubMed]

79. Kalagiri, R.R.; Carder, T.; Choudhury, S.; Vora, N.; Ballard, A.R.; Govande, V.; Drever, N.; Beeram, M.R.; Uddin, M.N. Inflammation in Complicated Pregnancy and Its Outcome. Am. J. Perinatol. 2016, 33, 1337-1356. [CrossRef]

80. Carlsen, S.M.; Romundstad, P.; Jacobsen, G. Early second-trimester maternal hyperandrogenemia and subsequent preeclampsia: A prospective study. Acta Obstet. Gynecol. Scand. 2005, 84, 117-121. [CrossRef]

81. Hsu, C.N.; Tain, Y.L. Light and Circadian Signaling Pathway in Pregnancy: Programming of Adult Health and Disease. Int. J. Mol. Sci. 2020, 21, 2232. [CrossRef]

82. Hsu, C.N.; Chan, J.Y.H.; Yu, H.R.; Lee, W.C.; Wu, K.L.H.; Chang-Chien, G.P.; Lin, S.; Hou, C.Y.; Tain, Y.L. Targeting on Gut Microbiota-Derived Metabolite Trimethylamine to Protect Adult Male Rat Offspring against Hypertension Programmed by Combined Maternal High-Fructose Intake and Dioxin Exposure. Int. J. Mol. Sci. 2020, 21, 5488. [CrossRef]

83. Hsu, C.N.; Lin, Y.J.; Lu, P.C.; Tain, Y.L. Maternal resveratrol therapy protects male rat offspring against programmed hypertension induced by TCDD and dexamethasone exposures: Is it relevant to aryl hydrocarbon receptor? Int. J. Mol. Sci. 2018, 19, 2459. [CrossRef] [PubMed]

84. Hsu, C.N.; Lin, Y.J.; Tain, Y.L. Maternal exposure to bisphenol A combined with high-fat diet-induced programmed hypertension in adult male rat offspring: Effects of resveratrol. Int. J. Mol. Sci. 2019, 20, 4382. [CrossRef] [PubMed]

85. Kirkley, A.G.; Sargis, R.M. Environmental endocrine disruption of energy metabolism and cardiovascular risk. Curr. Diab. Rep. 2014, 14, 494. [CrossRef] [PubMed]

86. Slotkin, T.A. Cholinergic systems in brain development and disruption by neurotoxicants: Nicotine, environmental tobacco smoke, organophosphates. Toxicol. Appl. Pharmacol. 2004, 198, 132-151. [CrossRef] [PubMed]

87. Xiao, D.; Huang, X.; Li, Y.; Dasgupta, C.; Wang, L.; Zhang, L. Antenatal Antioxidant Prevents Nicotine-Mediated Hypertensive Response in Rat Adult Offspring. Biol. Reprod. 2015, 93, 66. [CrossRef] [PubMed]

88. Gray, S.P.; Denton, K.M.; Cullen-McEwen, L.; Bertram, J.F.; Moritz, K.M. Prenatal exposure to alcohol reduces nephron number and raises blood pressure in progeny. J. Am. Soc. Nephrol. 2010, 21, 1891-1902. [CrossRef] [PubMed]

89. Serapiao-Moraes, D.F.; Souza-Mello, V.; Aguila, M.B.; Mandarim-de-Lacerda, C.A.; Faria, T.S. Maternal caffeine administration leads to adverse effects on adult mice offspring. Eur. J. Nutr. 2013, 52, 1891-1900. [CrossRef] [PubMed]

90. Slabiak-Blaz, N.; Adamczak, M.; Gut, N.; Grajoszek, A.; Nyengaard, J.R.; Ritz, E.; Wiecek, A. Administration of cyclosporine a in pregnant rats-The effect on blood pressure and on the glomerular number in their offspring. Kidney Blood Press. Res. 2015, 40, 413-423. [CrossRef] [PubMed]

91. Chahoud, I.; Stahlmann, R.; Merker, H.J.; Neubert, D. Hypertension and nephrotoxic lesions in rats 1 year after prenatal expo-sure to gentamicin. Arch. Toxicol. 1988, 62, 274-284. [CrossRef] [PubMed]

92. Hsu, C.N.; Chan, J.Y.H.; Wu, K.L.H.; Yu, H.R.; Lee, W.C.; Hou, C.Y.; Tain, Y.L. Altered Gut Microbiota and Its Metabolites in Hypertension of Developmental Origins: Exploring Differences between Fructose and Antibiotics Exposure. Int. J. Mol. Sci. 2021, 22, 2674. [CrossRef] [PubMed]

93. Gois, P.H.; Canale, D.; Luchi, W.M.; Volpini, R.A.; Veras, M.M.; Costa Nde, S.; Shimizu, M.H.; Seguro, A.C. Tenofovir during pregnancy in rats: A novel pathway for programmed hypertension in the offspring. J. Antimicrob. Chemother. 2015, 70, 1094-1105. [CrossRef] [PubMed]

94. Tain, Y.L.; Sheen, J.M.; Chen, C.C.; Yu, H.R.; Tiao, M.M.; Kuo, H.C.; Huang, L.T. Maternal citrulline supplementation prevents prenatal dexamethasone-induced programmed hypertension. Free Radic. Res. 2014, 48, 580-586. [CrossRef] [PubMed]

95. Tai, I.H.; Sheen, J.M.; Lin, Y.J.; Yu, H.R.; Tiao, M.M.; Chen, C.C.; Huang, L.T.; Tain, Y.L. Maternal N-acetylcysteine therapy regulates hydrogen sulfide-generating pathway and prevents programmed hypertension in male offspring exposed to prenatal dexamethasone and postnatal high-fat diet. Nitric Oxide 2016, 53, 6-12. [CrossRef] [PubMed]

96. Chang, H.Y.; Tain, Y.L. Postnatal dexamethasone-induced programmed hypertension is related to the regulation of melatonin and its receptors. Steroids 2016, 108, 1-6. [CrossRef] [PubMed]

97. Gwathmey, T.M.; Shaltout, H.A.; Rose, J.C.; Diz, D.I.; Chappell, M.C. Glucocorticoid-induced fetal programming alters the functional complement of angiotensin receptor subtypes within the kidney. Hypertension 2011, 57, 620-626. [CrossRef] [PubMed] 
98. Dodic, M.; Abouantoun, T.; O'Connor, A.; Wintour, E.M.; Moritz, K.M. Programming effects of short prenatal exposure to dexamethasone in sheep. Hypertension 2002, 40, 729-734. [CrossRef]

99. Tain, Y.L.; Hsu, C.N. Developmental Origins of Chronic Kidney Disease: Should We Focus on Early Life? Int. J. Mol. Sci. 2017, 18, 381. [CrossRef] [PubMed]

100. Tain, Y.L.; Lee, W.C.; Wu, K.; Leu, S.; Chan, J.Y.H. Maternal high fructose intake increases the vulnerability to post-weaning high-fat diet induced programmed hypertension in male offspring. Nutrients 2018, 10, 56. [CrossRef]

101. Dennery, P.A. Oxidative stress in development: Nature or nurture? Free Radic. Biol. Med. 2010, 49, 1147-1151. [CrossRef]

102. Tain, Y.L.; Lee, W.C.; Wu, K.L.H.; Leu, S.; Chan, J.Y.H. Resveratrol Prevents the Development of Hypertension Programmed by Maternal Plus Post-Weaning High-Fructose Consumption through Modulation of Oxidative Stress, Nutrient-Sensing Signals, and Gut Microbiota. Mol. Nutr. Food Res. 2018, 30, e1800066. [CrossRef] [PubMed]

103. Hsu, C.N.; Tain, Y.L. Developmental Origins of Kidney Disease: Why Oxidative Stress Matters? Antioxidants 2021, 10, 33. [CrossRef]

104. Te Riet, L.; van Esch, J.H.; Roks, A.J.; van den Meiracker, A.H.; Danser, A.H. Hypertension: Renin-angiotensin-aldosterone system alterations. Circ. Res. 2015, 116, 960-975. [CrossRef] [PubMed]

105. Gubler, M.C.; Antignac, C. Renin-angiotensin system in kidney development: Renal tubular dysgenesis. Kidney Int. 2010, 77, 400-406. [CrossRef] [PubMed]

106. Cragan, J.D.; Young, B.A.; Correa, A. Renin-Angiotensin System Blocker Fetopathy. J. Pediatr. 2015, 167, 792-794. [CrossRef] [PubMed]

107. Mullins, J.J.; Peters, J.; Ganten, D. Fulminant hypertension in transgenic rats harbouring the mouse Ren-2 gene. Nature 1990, 344 , 541-544. [CrossRef] [PubMed]

108. Woods, L.L.; Rasch, R. Perinatal ANG II programs adult blood pressure, glomerular number and renal function in rats. Am. J. Physiol. Regul. Integr. Comp. Physiol. 1998, 275, R1593-R1599. [CrossRef] [PubMed]

109. Hsu, C.N.; Tain, Y.L. Targeting the Renin-Angiotensin-Aldosterone System to Prevent Hypertension and Kidney Disease of Developmental Origins. Int. J. Mol. Sci. 2021, 22, 2298. [CrossRef] [PubMed]

110. Lin, Y.J.; Huang, L.T.; Tsai, C.C.; Sheen, J.M.; Tiao, M.M.; Yu, H.R.; Lin, I.C.; Tain, Y.L. Maternal high-fat diet sex-specifically alters placental morphology and transcriptome in rats: Assessment by next-generation sequencing. Placenta 2019, 78, 44-53. [CrossRef] [PubMed]

111. Wichi, R.B.; Souza, S.B.; Casarini, D.E.; Morris, M.; Barreto-Chaves, M.L.; Irigoyen, M.C. Increased blood pressure in the offspring of diabetic mothers. Am. J. Physiol. Regul. Integr. Comp. Physiol. 2005, 288, R1129-R1133. [CrossRef] [PubMed]

112. Hsu, C.N.; Wu, K.L.; Lee, W.C.; Leu, S.; Chan, J.Y.; Tain, Y.L. Aliskiren Administration during Early Postnatal Life Sex-Specifically Alleviates Hypertension Programmed by Maternal High Fructose Consumption. Front. Physiol. 2016, 7, 299. [CrossRef] [PubMed]

113. Manning, J.; Vehaskari, V.M. Postnatal modulation of prenatally programmed hypertension by dietary Na and ACE inhibition. Am. J. Physiol. Regul. Integr. Comp. Physiol. 2005, 288, R80-R84. [CrossRef] [PubMed]

114. Sherman, R.C.; Langley-Evans, S.C. Early administration of angiotensin-converting enzyme inhibitor captopril, prevents the development of hypertension programmed by intrauterine exposure to a maternal low-protein diet in the rat. Clin. Sci. 1998, 94, 373-381. [CrossRef]

115. Bessa, A.S.M.; Jesus, É.F.; Nunes, A.D.C.; Pontes, C.N.R.; Lacerda, I.S.; Costa, J.M.; Souza, E.J.; Lino-Júnior, R.S.; Biancardi, M.F.; Dos Santos, F.C.A.; et al. Stimulation of the ACE2/Ang-(1-7)/Mas axis in hypertensive pregnant rats attenuates cardiovascular dysfunction in adult male offspring. Hypertens. Res. 2019, 42, 1883-1893. [CrossRef] [PubMed]

116. Bertram, J.F.; Douglas-Denton, R.N.; Diouf, B.; Hughson, M.D.; Hoy, W.E. Human nephron number: Implications for health and disease. Pediatr. Nephrol. 2011, 26, 1529-1533. [CrossRef] [PubMed]

117. Luyckx, V.A.; Brenner, B.M. The clinical importance of nephron mass. J. Am. Soc. Nephrol. 2010, 21, 898-910. [CrossRef] [PubMed]

118. Tain, Y.L.; Chan, S.H.H.; Chan, J.Y.H. Biochemical basis for pharmacological intervention as a reprogramming strategy against hypertension and kidney disease of developmental origin. Biochem. Pharmacol. 2018, 153, 82-90. [CrossRef] [PubMed]

119. Vehaskari, V.M.; Stewart, T.; Lafont, D.; Soyez, C.; Seth, D.; Manning, J. Kidney angiotensin and angiotensin receptor expression in prenatally programmed hypertension. Am. J. Physiol. Ren. Physiol. 2004, 287, F262-F267. [CrossRef]

120. Hao, X.Q.; Zhang, H.G.; Yuan, Z.B.; Yang, D.L.; Hao, L.Y.; Li, X.H. Prenatal exposure to lipopolysaccharide alters the intrarenal renin-angiotensin system and renal damage in offspring rats. Hypertens. Res. 2010, 33, 76-82. [CrossRef] [PubMed]

121. Walton, S.L.; Bielefeldt-Ohmann, H.; Singh, R.R.; Li, J.; Paravicini, T.M.; Little, M.H.; Moritz, K.M. Prenatal hypoxia leads to hypertension, renal renin-angiotensin system activation and exacerbates salt-induced pathology in a sex-specific manner. Sci. Rep. 2017, 7, 8241. [CrossRef] [PubMed]

122. Tamburini, S.; Shen, N.; Wu, H.C.; Clemente, J.C. The microbiome in early life: Implications for health outcomes. Nat. Med. 2016, 22, 713-722. [CrossRef]

123. Stiemsma, L.T.; Michels, K.B. The role of the microbiome in the developmental origins of health and disease. Pediatrics 2018, 141, e20172437. [CrossRef] [PubMed]

124. Krautkramer, K.A.; Kreznar, J.H.; Romano, K.A.; Vivas, E.I.; Barrett-Wilt, G.A.; Rabaglia, M.E.; Keller, M.P.; Attie, A.D.; Rey, F.E.; Denu, J.M. Diet-Microbiota Interactions Mediate Global Epigenetic Programming in Multiple Host Tissues. Mol. Cell 2016, 64, 982-992. [CrossRef] [PubMed] 
125. Khodor, S.A.; Reichert, B.; Shatat, I.F. The Microbiome and Blood Pressure: Can Microbes Regulate Our Blood Pressure? Front. Pediatr. 2017, 5, 138. [CrossRef] [PubMed]

126. Hsu, C.N.; Hou, C.Y.; Chang-Chien, G.P.; Lin, S.; Tain, Y.L. Maternal Garlic Oil Supplementation Prevents High-Fat Diet-induced Hypertension in Adult Rat Offspring: Implications of H2S-generating Pathway in the Gut and Kidneys. Mol. Nutr. Food Res. 2021, e2001116. [CrossRef] [PubMed]

127. Hsu, C.N.; Lin, Y.J.; Hou, C.Y.; Tain, Y.L. Maternal Administration of Probiotic or Prebiotic Prevents Male Adult Rat Offspring against Developmental Programming of Hypertension Induced by High Fructose Consumption in Pregnancy and Lactation. Nutrients 2018, 10, 1229. [CrossRef]

128. Hsu, C.N.; Hou, C.Y.; Chan, J.Y.H.; Lee, C.T.; Tain, Y.L. Hypertension Programmed by Perinatal High-Fat Diet: Effect of Maternal Gut Microbiota-Targeted Therapy. Nutrients 2019, 11, 2908. [CrossRef] [PubMed]

129. Lankelma, J.M.; Nieuwdorp, M.; de Vos, W.M.; Wiersinga, W.J. The gut microbiota in internal medicine: Implications for health and disease. Neth. J. Med. 2015, 73, 61-68. [PubMed]

130. Ojeda, N.B.; Intapad, S.; Alexander, B.T. Sex differences in the developmental programming of hypertension. Acta Physiol. 2014, 210, 307-316. [CrossRef] [PubMed]

131. Tomat, A.L.; Salazar, F.J. Mechanisms involved in developmental programming of hypertension and renal diseases. Gender differences. Horm. Mol. Biol. Clin. Investig. 2014, 18, 63-77. [CrossRef]

132. Vina, J.; Gambini, J.; Lopez-Grueso, R.; Abdelaziz, K.M.; Jove, M.; Borras, C. Females live longer than males: Role of oxidative stress. Curr. Pharm. Des. 2011, 17, 3959-3965. [CrossRef] [PubMed]

133. Hilliard, L.M.; Sampson, A.K.; Brown, R.D.; Denton, K.M. The "his and hers" of the renin-angiotensin system. Curr. Hypertens. Rep. 2013, 15, 71-79. [CrossRef]

134. Beale, A.L.; Kaye, D.M.; Marques, F.Z. The role of the gut microbiome in sex differences in arterial pressure. Biol. Sex. Differ. 2019, 10, 22. [CrossRef]

135. Tain, Y.L.; Wu, M.S.; Lin, Y.J. Sex differences in renal transcriptome and programmed hypertension in offspring exposed to prenatal dexamethasone. Steroids 2016, 115, 40-46. [CrossRef] [PubMed]

136. Tain, Y.L.; Hsu, C.N. Interplay between oxidative stress and nutrient sensing signaling in the developmental origins of cardiovascular disease. Int. J. Mol. Sci. 2017, 18, 841. [CrossRef] [PubMed]

137. Kett, M.M.; Denton, K.M. Renal programming: Cause for concern? Am. J. Physiol. Regul. Integr. Comp. Physiol. 2011, 300, R791-R803. [CrossRef] [PubMed]

138. Bogdarina, I.; Welham, S.; King, P.J.; Burns, S.P.; Clark, A.J. Epigenetic modification of the renin-angiotensin system in the fetal programming of hypertension. Circ. Res. 2007, 100, 520-526. [CrossRef] [PubMed]

139. Cavanal Mde, F.; Gomes, G.N.; Forti, A.L.; Rocha, S.O.; Franco Mdo, C.; Fortes, Z.B.; Gil, F.Z. The influence of L-arginine on blood pressure, vascular nitric oxide and renal morphometry in the offspring from diabetic mothers. Pediatr. Res. 2007, 62, 145-150. [CrossRef]

140. Thaeomor, A.; Teangphuck, P.; Chaisakul, J.; Seanthaweesuk, S.; Somparn, N.; Roysommuti, S. Perinatal Taurine Supplementation Prevents Metabolic and Cardiovascular Effects of Maternal Diabetes in Adult Rat Offspring. Adv. Exp. Med. Biol. 2017, 975, 295-305. [PubMed]

141. Torrens, C.; Brawley, L.; Anthony, F.W.; Dance, C.S.; Dunn, R.; Jackson, A.A.; Poston, L.; Hanson, M.A. Folate supplementation during pregnancy improves offspring cardiovascular dysfunction induced by protein restriction. Hypertension 2006, 47, $982-987$. [CrossRef] [PubMed]

142. Hsu, C.N.; Tain, Y.L. Regulation of Nitric Oxide Production in the Developmental Programming of Hypertension and Kidney Disease. Int. J. Mol. Sci. 2019, 20, 681. [CrossRef]

143. Wesseling, S.; Essers, P.B.; Koeners, M.P.; Pereboom, T.C.; Braam, B.; van Faassen, E.E.; Macinnes, A.W.; Joles, J.A. Perinatal exogenous nitric oxide in fawn-hooded hypertensive rats reduces renal ribosomal biogenesis in early life. Front. Genet. 2011, 2, 52. [CrossRef]

144. Uson-Lopez, R.A.; Kataoka, S.; Mukai, Y.; Sato, S.; Kurasaki, M. Melinjo (Gnetum gnemon) Seed Extract Consumption during Lactation Improved Vasodilation and Attenuated the Development of Hypertension in Female Offspring of Fructose-Fed Pregnant Rats. Birth Defects Res. 2018, 110, 27-34. [CrossRef] [PubMed]

145. Hsu, C.N.; Tain, Y.L. Preventing Developmental Origins of Cardiovascular Disease: Hydrogen Sulfide as a Potential Target? Antioxidants 2021, 10, 247. [CrossRef] [PubMed]

146. Hsu, C.N.; Lin, Y.J.; Lu, P.C.; Tain, Y.L. Early supplementation of D-cysteine or L-cysteine prevents hypertension and kidney damage in spontaneously hypertensive rats exposed to high-salt intake. Mol. Nutr. Food Res. 2018, 62, 2. [CrossRef] [PubMed]

147. Xiao, D.; Wang, L.; Huang, X.; Li, Y.; Dasgupta, C.; Zhang, L. Protective Effect of Antenatal Antioxidant on Nicotine-Induced Heart Ischemia-Sensitive Phenotype in Rat Offspring. PLoS ONE 2016, 11, e0150557. [CrossRef] [PubMed]

148. Feng, X.; Guo, Q.; Xue, H.; Duan, X.; Jin, S.; Wu, Y. Hydrogen Sulfide Attenuated Angiotensin II-Induced Sympathetic Excitation in Offspring of Renovascular Hypertensive Rats. Front. Pharmacol. 2020, 11, 565726. [CrossRef] [PubMed]

149. Tain, Y.L.; Hsu, C.N. AMP-Activated Protein Kinase as a Reprogramming Strategy for Hypertension and Kidney Disease of Developmental Origin. Int. J. Mol. Sci. 2018, 19, 1744. [CrossRef] [PubMed] 
150. Torres, T.S.; D’Oliveira Silva, G.; Aguila, M.B.; de Carvalho, J.J.; Mandarim-De-Lacerda, C.A. Effects of rosiglitazone (a peroxysome proliferator-activated receptor $\gamma$ agonist) on the blood pressure and aortic structure in metabolically programmed (perinatal low protein) rats. Hypertens. Res. 2008, 31, 965-975. [CrossRef] [PubMed]

151. Gray, C.; Vickers, M.H.; Segovia, S.A.; Zhang, X.D.; Reynolds, C.M. A maternal high fat diet programmes endothelial function and cardiovascular status in adult male offspring independent of body weight, which is reversed by maternal conjugated linoleic acid (CLA) supplementation. PLoS ONE 2015, 10, e0115994.

152. Yousefipour, Z.; Newaz, M. PPAR $\alpha$ ligand clofibrate ameliorates blood pressure and vascular reactivity in spontaneously hypertensive rats. Acta Pharmacol. Sin. 2014, 35, 476-482. [CrossRef] [PubMed]

153. Wu, L.; Wang, R.; de Champlain, J.; Wilson, T.W. Beneficial and deleterious effects of rosiglitazone on hypertension development in spontaneously hypertensive rats. Am. J. Hypertens. 2004, 17, 749-756. [CrossRef] [PubMed]

154. Tain, Y.L.; Hsu, C.N.; Chan, J.Y. PPARs link early life nutritional insults to later programmed hypertension and metabolic syndrome. Int. J. Mol. Sci. 2015, 17, 20. [CrossRef] [PubMed]

155. Hunter, D.S.; Hazel, S.J.; Kind, K.L.; Owens, J.A.; Pitcher, J.B.; Gatford, K.L. Programming the brain: Common outcomes and gaps in knowledge from animal studies of IUGR. Physiol. Behav. 2016, 164, 233-248. [CrossRef] [PubMed]

156. Rosenblum, S.; Pal, A.; Reidy, K. Renal development in the fetus and premature infant. Semin. Fetal Neonatal Med. 2017, $22,58-66$. [CrossRef] [PubMed]

157. Hartman, H.A.; Lai, H.L.; Patterson, L.T. Cessation of renal morphogenesis in mice. Dev. Biol. 2007, 310, 379-387. [CrossRef] [PubMed]

158. Sengupta, P. The Laboratory Rat: Relating Its Age with Human's. Int. J. Prev. Med. 2013, 4, 624-630. [PubMed]

159. Chahoud, I.; Paumgartten, F.J.R. Influence of litter size on the postnatal growth of rat pups: Is there a rationale for litter-size standardization in toxicity studies? Environ. Res. 2009, 109, 1021-1027. [CrossRef] [PubMed]

160. Barry, J.S.; Anthony, R.V. The pregnant sheep as a model for human pregnancy. Theriogenology 2008, 69, 55-67. [CrossRef] [PubMed]

161. Van Abeelen, A.F.; Veenendaal, M.V.; Painter, R.C.; de Rooij, S.R.; Thangaratinam, S.; van der Post, J.A.; Bossuyt, P.M.; Elias, S.G.; Uiterwaal, C.S.; Grobbee, D.E.; et al. The fetal origins of hypertension: A systematic review and meta-analysis of the evidence from animal experiments of maternal undernutrition. J. Hypertens. 2012, 30, 2255-2267. [CrossRef]

162. Krege, J.H.; Hodgin, J.B.; Hagaman, J.R.; Smithies, O. A noninvasive computerized tail-cuff system for measuring blood pressure in mice. Hypertension 1995, 25, 1111-1115. [CrossRef] [PubMed]

163. Morrison, J.L.; Botting, K.J.; Darby, J.R.T.; David, A.L.; Dyson, R.M.; Gatford, K.L.; Gray, C.; Herrera, E.A.; Hirst, J.J.; Kim, B.; et al. Guinea pig models for translation of the developmental origins of health and disease hypothesis into the clinic. J. Physiol. 2018, 596, 5535-5569. [CrossRef] [PubMed]

164. Gonzalez-Bulnes, A.; Astiz, S.; Ovilo, C.; Lopez-Bote, C.J.; Torres-Rovira, L.; Barbero, A.; Ayuso, M.; Garcia-Contreras, C.; Vazquez-Gomez, M. Developmental Origins of Health and Disease in swine: Implications for animal production and biomedical research. Theriogenology 2016, 86, 110-119. [CrossRef] [PubMed]

165. Kuo, A.H.; Li, C.; Li, J.; Huber, H.F.; Nathanielsz, P.W.; Clarke, G.D. Cardiac remodeling in a baboon model of intrauterine growth restriction mimics accelerated ageing. J. Physiol. 2017, 595, 1093-1110. [CrossRef] [PubMed]

166. Haider, B.A.; Bhutta, Z.A. Multiple-micronutrient supplementation for women during pregnancy. Cochrane Database Syst. Rev. 2017, 4, CD004905. [CrossRef] [PubMed]

167. Schwarzenberg, S.J.; Georgieff, M.K.; Committee on Nutrition. Advocacy for Improving Nutrition in the First 1000 Days to Support Childhood Development and Adult Health. Pediatrics 2018, 141, e20173716. [CrossRef] [PubMed]

168. Safi-Stibler, S.; Gabory, A. Epigenetics and the Developmental Origins of Health and Disease: Parental environment signalling to the epigenome, critical time windows and sculpting the adult phenotype. Semin. Cell Dev. Biol. 2020, 97, 172-180. [CrossRef] 